\title{
Breast necrosis induced by the use of coumadin: case report and review of literature
}

\author{
Necrose mamária induzida pelo uso de cumarínico: relato de caso e revisão da literatura \\ Dani Ejzenberg ${ }^{1}$, Lucienne Pereira Del Grossi Neusquen ${ }^{1}$, Daniel Lorber Rolnik ${ }^{1}$, \\ Adriana Chebar Lozinsky², José Roberto Morales Piato ${ }^{1}$
}

\begin{abstract}
The coumadin-induced skin necrosis is rare and occurs more frequently in the breasts, thighs and buttocks. We describe the first case of coumadin necrosis of the breast in Brazil in a 62-year-old patient.
\end{abstract}

Keywords: Necrosis/chemically induced; Warfarin/adverse effects; Breast/pathology; Case reports

\section{RESUMO}

A necrose cutânea induzida por cumarínicos é um evento raro e ocorre com maior frequência nas mamas, coxas e nádegas. Descrevemos 0 primeiro caso de necrose cumarínica das mamas no Brasil em paciente de 62 anos.

Descritores: Necrose/quimicamente induzido; Varfarina/efeitos adversos; Mama/patologia; Relatos de casos

\section{INTRODUCTION}

Anticoagulant therapy is commonly prescribed in the medical practice and one of the most used is sodium warfarin.

Skin and subcutaneous tissue necrosis is an extremely rare complication, and its incidence ranges from $0.01 \%$ to $0.1 \%$. The most common affected sites by this necrosis are breast, buttocks and thighs. ${ }^{(1)}$ The first case of skin necrosis affecting the breast was reported by Flood et al. in 1943.(2) Since then, almost 200 cases of skin necrosis have been reported so far, but less than 40 cases involved the breast tissue. ${ }^{(3)}$
This event has an irreversible course of action, and early diagnosis and surgical debridement are recommended to prevent significant morbidity and mortality. ${ }^{(4)}$

\section{CASE REPORT}

A 62-year-old patient was admitted to the Hospital das Clínicas, in São Paulo (SP), because of pain in her right breast, swelling and darkening which had commenced 3 days before. The symptoms started on the nipple and spread to the whole right breast. Six days before the onset of the complaints, she started to take sodium warfarin $2.5 \mathrm{mg}$ /day, for treatment of deep vein thrombosis on her left leg, however, she did not receive heparin simultaneously. The thrombosis occurred due to complications of a first brachytherapy session to treat an advanced cervical cancer. The patient was also taking angiotensin-converting enzyme inhibitor (captopril $150 \mathrm{mg} /$ day) for arterial hypertension and phenobarbital 50mg/day for epilepsy. She denied regular alcohol intake or smoking.

Upon admission, she was in regular general condition, without fever, and blood pressure of 130x90mmHg. Her body mass index was 32 . The abdominal, pulmonary and cardiologic tests were normal. Her left breast was normal while right breast was swollen and had a large ulceration with a necrotic basis involving the nipple and the central area (Figure 1).

\footnotetext{
' Hospital das Clínicas, Faculdade de Medicina, Universidade de São Paulo, São Paulo, SP, Brazil.

2 Faculdade de Medicina do ABC, Santo André, SP, Brazil.

Corresponding author: Dani Ejzenberg - Avenida Republica do Líbano, 1,843 - Ibirapuera - Zip code: 04501-002 - São Paulo, SP, Brazil - Phone: (55 11) 5055-1010 - E-mail: daejz@hotmail.com Received on: Apr 12, 2013 - Accepted on: Feb 17, 2014

DOI: 10.1590/\$1679-45082015RC2829
} 


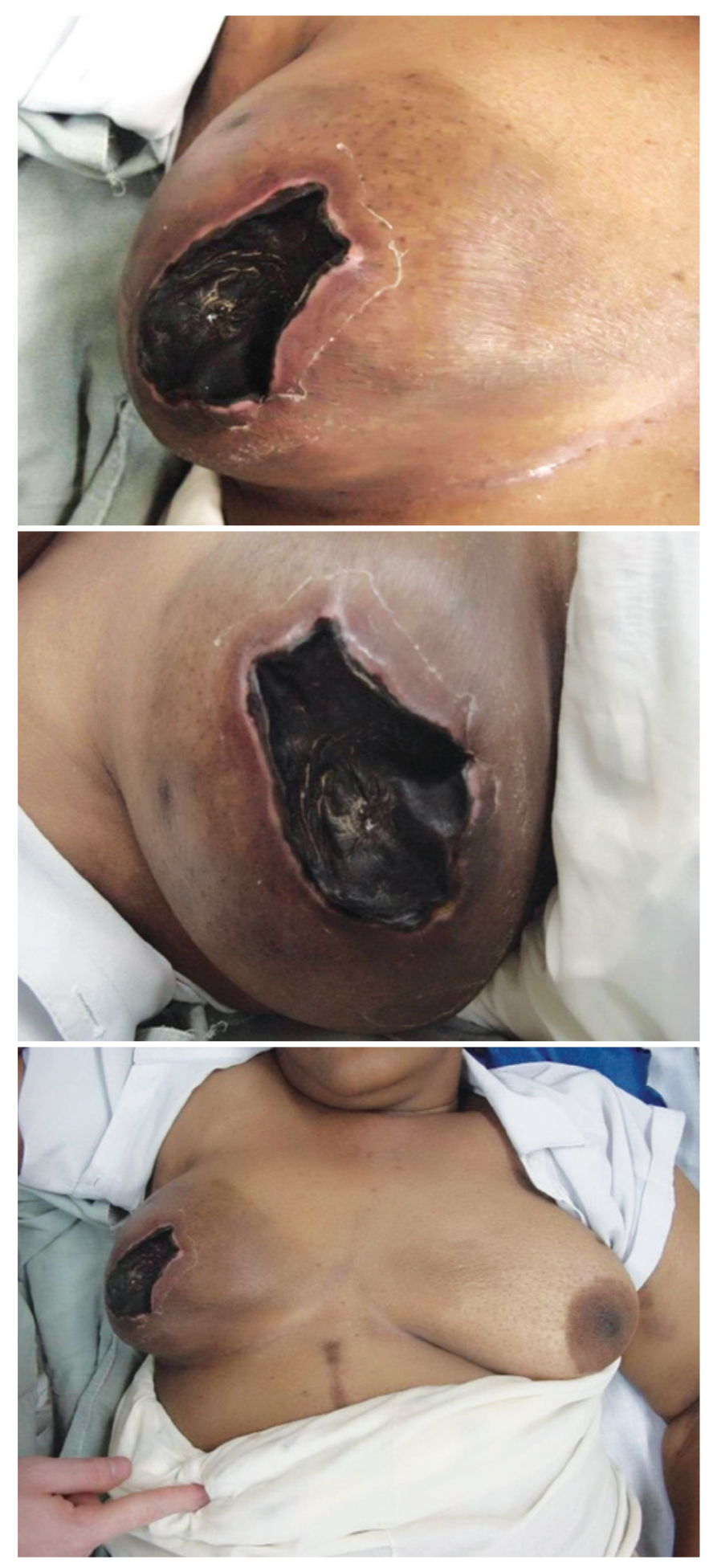

Figure 1. Coumadin necrosis of the right breast

Laboratory tests showed hematocrit of $29 \%$, hemoglobin of $9.8 \mathrm{mg} / \mathrm{dL}$, white cells count of 6,450 and a platelet count of $142,000 / \mathrm{mL}$. Prothrombin time was 14.7 seconds (normal: 11 seconds) with an international normalized ratio (INR) of 1.3 and normal partial thromboplastin time. Her fibrinogen was normal and fibrin-split products were high $(578 \mu \mathrm{g} / \mathrm{mL})$. The diagnostic hypothesis was necrosis due to warfarin use on the right breast. After diagnosis, the patients initiated treatment with high doses of heparin and vitamin K. After four days of treatment no improvements were seen and the patient was submitted to simple mastectomy. No intercurrence was observed and heparin administration was re-initiated 12 hours after the surgery. The patient did well postoperatively and was discharged. An adequate anticoagulant therapy with a warfarin dose of $2.5 \mathrm{mg} /$ day was established, without further complications.

\section{DISCUSSION}

Skin necrosis is an unusual complication of anticoagulant therapy, and the breast involvement occurs only 10 to $15 \%$ of cases. ${ }^{(3)}$ The majority of necrotic lesions appears in areas of excessive subcutaneous tissue. Such lesions often affect breasts, thighs, arms, buttocks, hands, digits, legs, feet, nose, face, abdomen, back and penis. ${ }^{(5)}$ Women are much more affected than men. Currently, multiple lesions have been reported in $35 \%$ of the cases, sometimes symmetrically. ${ }^{(3,5)}$

A literature review of reports in English language including 25 papers described 38 reports of breast necrosis after the use of warfarin. In these reports, patients' age ranged 16 to 93 years old. ${ }^{(3,5)}$ No significant difference between the involvement of right and left breasts was reported, being bilateral necrosis also observed. ${ }^{(5,6)}$ Typically, this condition is seen in middleaged obese women who are receiving warfarin therapy for deep venous thrombosis or other thromboembolic diseases, such as the case we report here. ${ }^{(1,2)}$

The initial lesion is a well-defined erythematous and painful area, which appears in 3 to 6 days after the beginning of anticoagulation. ${ }^{(6,7)}$ This area may develop a peau d'orange aspect. ${ }^{(5)}$ The area evolves into a black ecchymosed area, which progresses to dry gangrene. ${ }^{(5,6)}$ Histology shows cutaneous infarcts, haemorrhages, breakdown of precapillary arterioles, fibrin deposits and no evidence of vascular or perivascular inflammation. ${ }^{(1,6,7)}$ Some advanced cases can mimic inflammatory carcinoma, and that is why early biopsy helps in the differential diagnosis. $^{(1)}$

The exact etiology and the reason for its predilection for fat tissue remain unclear, but many authors believe that it is a multifactorial condition, which can include trauma, inadequate blood perfusion and variation of temperature. ${ }^{(1,5,7)}$ The probable mechanism unleashing this complication is a small cutaneous vessels thrombosis due to the inhibition of proteins $\mathrm{C}$ and $\mathrm{S}$, and vitamin K-dependent endogenous anticoagulants. Such situation 
occurs before the inhibition of other factors and leads to thrombotic tendency among people who have homozigotic, heterozigotic or acquired protein $\mathrm{C}$ or $\mathrm{S}$ deficiencies. ${ }^{(8,9)}$ For this reason, many authors recommend the concomitant administration of heparin in the first days of the anticoagulant therapy. ${ }^{(9)}$

Once diagnosed, high doses of heparin should be administered, besides administration of vitamin $\mathrm{K}$ in order to restore proteins $\mathrm{C}$ and $\mathrm{S}$ levels. ${ }^{(1,6)}$ The treatment includes the discontinuation of warfarin treatment, but this approach has not been shown to change the outcome. Success has been reported in careful recommencement of warfarin therapy, which in the beginning should be always associated to parenteral anticoagulation. ${ }^{(6)}$ Significant morbidity and several deaths have been also reported. ${ }^{(1,6,10)}$ Despite that conservative treatment should be considered and half of cases requires surgical debridement, ${ }^{(1,2,7)}$ eventually mastectomy is needed. ${ }^{(1,7)}$ No evidence was found regarding risk of skin necrosis by angiotensin-converting enzyme inhibitors as well as by phenobarbital. Moreover, antiepileptic drugs tend to reduce anticoagulants action. ${ }^{(8)}$

The usual characteristics founded in this case report corroborate with literature. In spite of complications presented: woman, 62-years-old, obese, necrosis occurrence on 6th day after introduction of oral anticoagulants for venous thrombosis. Despite the reduced dose and suspension of drug after the diagnosis, a simple mastectomy was necessary, because of the rapid evolution to the skin necrosis.

\section{REFERENCES}

1. DeFranzo AJ, Marasco P, Argenta LC. Warfarin-induced necrosis of the skin Ann Plast Surg. 1995;34(2):203-8. Review.

2. Flood EP, RedishMH, Bociek SJ, Shapiro S. Piletromboflebites migrans disseminate: report of a case in which gangrene of the breast occurred. Observations on the therapeutic use of dicumarol (3,3'methylenebis(4-hydroxycoumarin). N Y State J Med. 1943;43:1121-4

3. Au AF, Fosnot J, Wu LC. Coumadin-induced skin necrosis of the breasts: case report. Ann Plast Surg. 2012;69(1):109-10. Review.

4. Kagan RJ, Glassford GH. Coumadin-induced breast necrosis. Am Surg. 1981; 47(11):509-10.

5. Khalid K. Warfarin-induced necrosis of the breast: case report. J Postgrad Med. 2004;50(4):268-9.

6. Chan YC, Valenti D, Mansfield AO, Stansby G. Warfarin induced skin necrosis. Br J Surg. 2000;87(3):266-72. Review.

7. López Valle CA, Hébert G. Warfarin-induced complete bilateral breast necrosis. Br J Plast Surg. 1992;45(8):606-9. Review.

8. Bucciarelli P, Rosendaal FR, Tripodi A, Mannucci PM, De Stefano V, Palareti $\mathrm{G}$, et al. Risk of venous thromboembolism and clinical manifestations in carriers of antithrombin, protein C, protein $\mathrm{S}$ deficiency, or activated protein $\mathrm{C}$ resistance: a multicenter collaborative family study. Arterioscler Thromb Vasc Biol. 1999;19(4):1026-33.

9. Dahlbäck B, Villoutreix BO. The anticoagulant protein C pathway. FEBS Lett. 2005;579(15):3310-6. Review.

10. Ad-El DD, Meirovitz A, Weinberg A, Kogan L, Arieli D, Neuman A, et al. Warfarin skin necrosis: local and systemic factors. Br J Plast Surg. 2000;53(7):624-6. 